JED

24,2

176

Received 24 December 2020 Revised 10 April 2021 15 June 2021

Accepted 28 July 2021

\section{Comparative effect of short-term credit granted to agriculture on agricultural added value in the West African countries}

\author{
Laurent Oloukoi \\ Faculté des Sciences Economiques et de Gestion, Université de Parakou, \\ Parakou, Bénin
}

\begin{abstract}
Purpose - The paper analyzes the response of agricultural value added to credit and real interest rate shocks in the West African Economic and Monetary Union (WAEMU) and make a short-term comparative effect analysis of credit granted to the agricultural sector on agricultural value added among member countries.

Design/methodology/approach - First, in order to estimate impulse response functions (IRFs) and study shocks, a panel VAR model is used. Second the paper uses an autoregressive distributed lag (ARDL) model with the associated error correction model to make a comparative analysis of the effect of agricultural credit on agricultural value added in the WAEMU.

Findings - Results shows that: (1) credit stimulates agricultural value added only in the medium and long term; (2) in the case of WAEMU, credit only becomes a means of lifting the constraint of capital underutilization after three years; (3) short-term credit granted to agriculture in WAEMU has a weak and differentiated effect on agricultural value added from one country to another.

Practical implications - It is imperative to implement a policy of lowering real short-term interest rates. Moreover, a monetary policy that favors direct financing of agriculture to the detriment of that oriented toward market financing is to be prioritized.

Originality/value - The originality of this paper is that it makes the link between macroeconomics and agriculture. It shows how the monetary instrument can be manipulated to improve the performance of agriculture. Actually, in WAEMU, the financing of agriculture is provided by the market. This paper proposes a new approach which is direct financing. The paper offers possibilities for the coordination of agricultural policies in the WAEMU.
\end{abstract}

Keywords Agriculture, Growth, Credit, Interest rates, WAEMU

Paper type Research paper

\section{Introduction}

Several studies have analyzed the determinants of economic growth. These studies can be classified into two main groups: the so-called orthodox models (neoclassical and endogenous growth theories) and post-Keynesian models. For the orthodox group, the growth differential between countries is explained by the availability and quality of production factors. The key role of production factors and technical progress is therefore highlighted. Each country maximizes its well-being through activities in which it is more efficient in terms of factors of production and scarcity of resources. According to the orthodox group, trade liberalization affects only income and has any positive effect on economic growth (Duncan and Quang, 2001). Indeed, since the benefits of trade are static, trade liberalization cannot lead to an increase in the long-term growth rate. This idea was perceived by traditional international

(c) Laurent Oloukoi. Published in Journal of Economics and Development. Published by Emerald Publishing Limited. This article is published under the Creative Commons Attribution (CC BY 4.0) licence. Anyone may reproduce, distribute, translate and create derivative works of this article (for both commercial and non-commercial purposes), subject to full attribution to the original publication and authors. The full terms of this licence may be seen at http://creativecommons.org/licences/by/4.0/ legalcode 
trade theory and Hecksher-Ohlin-Samuelson's analysis, which shows that trade influences the economy through the level and composition of output without influencing long-term growth. With the advent of endogenous growth theory, the key role of trade policies as a determinant of long term economic growth will be highlighted. Hence, trade policies can have some influence on both the level and rate of long term economic growth. Foreign trade can have an impact on economic growth as soon as market shares increase. This is achieved through economies of scale that are captured in production. In other words, trade openness increases market opportunities for local producers, improves economic efficiency and in turn, causes countries to specialize in knowledge and research based production. The other advantage of trade openness is that it reduces price volatility as argued by the physiocrats. Vickers and Yarrow (1991) focus on trade openness, which improves countries' competitiveness and promote economic growth. Indeed, increasing the size of markets allows countries to better exploit the potential benefits of increasing returns to scale. It should be noted that neoclassical theory does not focus on demand as a determinant of economic growth. The second major group of work is essentially post-Keynesian theory. Here, the main determinant of economic growth is demand and not supply. In this vein, Thirlwall (1979) formulated the "balance-ofpayment constrained theory of economic growth. This theory is initiated by Harrod (1933) through the concept of the dynamic multiplier of foreign trade. It is a theory that is part of a post-Keynesian tradition that seeks to explain growth by factors related to external demand. In this tradition, Thirlwall's (1979) model becomes a reference. A country wishing to accelerate its economic growth must first remove the balance of payments constraint on demand. According to Setterfield (2003), demand influences the accumulation of production capacity in terms of capital and labor. Foreign demand is therefore seen as a determining factor in economic growth. Blecker (2010) examines the role of foreign demand in the economic growth process. Yongbok (2009) and Ozturk and Acaravci (2010) find that GDP growth was consistent with the balance of payment for China, Pakistan and South Africa, respectively. Hussain (2002), in his research, concludes that the observed and predicted growth rates in Asia are much higher than those of African countries because of their low dynamic trade multiplier.

This paper seeks to analyze the determinants of agricultural growth in the WAEMU. It focuses on the particular role of short-term credit granted to the agricultural sector and the interest rate. Indeed, agriculture plays an important role in the economic growth of nations. The neoclassical conception considers agriculture as an engine for industrialization (Ruan, 2017). From this point of view, agriculture is the sector that generates raw materials that are indispensable for the development of industries. Johnston and Mellor (1961) make five propositions that show how increased agricultural production and productivity contribute to overall economic growth: (1) a substantial increase in demand for agricultural products; (2) an increase in income due to the expansion of agricultural exports; (3) a surplus of labor derived mainly from agriculture; (4) a net contribution to the capital needed for indirect investment and the expansion of secondary industry; and (5) an increase in the income of the agricultural population to stimulate industrial expansion. In a case study in Pakistan, Khan (1967) shows that the transformation of agriculture, through increased productivity, enables farmers to meet the food needs of the urban and industrial population (avoiding inflation) on one hand and enables the agricultural sector to free up the labor force needed for industrial expansion on the other hand. Kuznets (1971) goes on to enumerate that a competitive agriculture must be able to assume three main roles: first, to be able to participate in growth; second, to increase the incomes of agricultural producers; and third, to contribute to the financing of other sectors of the economy. In order to bring agriculture to ful fil its roles, agricultural policy reforms are being initiated in countries.

In order to incite agriculture to assume its roles in WAEMU, agricultural policy reforms are being initiated, notably the WAEMU Agricultural Policy (PAU). The PAU thus aims to contribute in a sustainable manner to meeting the food needs of the population, to the social and economic development of member states and to poverty reduction. Despite the reforms 
JED

24,2

undertaken, it must be noted that the agricultural sector in the WAEMU continues to be undermined by poor performance, which cause doubt on the real effectiveness of the agricultural policies implemented. Indeed, according to a report by the African Development Bank (2016), the decline of the agricultural sector also stems from limited access to arable land and lack of financing. This result of the African Development Bank shows that credit remains a major constraint in the agricultural sector.

This paper makes the link between macroeconomics and agriculture. It shows how the monetary instrument can be manipulated to improve the performance of agriculture in WAEMU. Actually, in WAEMU, the financing of agriculture is provided by the market. Indeed, the credit amount granted to agriculture is fixed by the market through supply and demand low. This situation characterized by the laissez-faire markets is source credit restriction for the farmer. The paper proposes a new approach, which is direct financing. The paper in addition to the introduction, presents the methodology, the results, discussions and conclusion.

\section{Literature review}

\subsection{The determinants of economic growth}

The economic literature presents clearly the determinants of economic growth. According to Anyanwu (2014), the most fundamental determinant of economic growth identified by both neoclassical and endogenous growth models is investment hence a lot of empirical work focus on it. Anetor (2018), using the impulse response function (IRF) and the forecast error variance decomposition of the structural vector autoregression (SVAR) model, finds in the case of Nigeria that shocks in foreign direct investment (FDI) inflows and portfolio investment inflows have a positive and significant impact on economic growth in Nigeria. In addition, FDIs accounted for significant variation in the growth of the Nigerian economy followed by portfolio investments, while personal remittances exerted the least variation in growth. Others factors affecting economic growth are government consumption, real per capita GDP, initial schooling and life expectancy, fertility level, inflation, terms of trade (Barro, 2003).

Anyanwu (2011) analyses the effects of foreign aid on Africa's economic growth. His study is based on time series data from 1958 to 2001. The principal conclusion of his work is that aid has a positive impact on growth, and that the impact does not depend on the policy environment. With the development of the trade liberalization and the aid for trade theories, several determinants of growth emerged: the trade openness which improve countries' competitiveness and promote economic growth (Vickers and Yarrow, 1991), the aid for trade which affects welfare effects (Mayer and Milberg, 2013). Beyond aid flows, Lensink and Morrissey (1999) consider the stability of aid flows. Instantly estimating a growth model including level, they show that the effect of aid is not significant; taking instability into account, the effect of aid flows on economic growth becomes significant. The stability test also indicates that the significant effect is the result of the investment channel. Ferro, Portugal-Perez and Wilson (2011) show that trade facilitation reforms improve export performance in developing countries. This is particularly true with investment in physical infrastructure and regulatory reform to improve the business environment. Ultimately, the relationship between aid and growth is not clear. There are two effects in general in the literature. On the one hand, there is a positive effect supported by authors such as Rosenstein-Rodan (1961), Chenery and Strout (1968) where aid favors growth by allowing the State to relax its budgetary constraints while improving its investments. On the other hand, misappropriation of aid directed primarily at consumer spending can have a negative influence on growth. These mixed effects of aid on economic growth have led researchers to focus their work on the conditions that determine aid effectiveness.

In the case study of Ghana, Gatsi and Appiah (2020) found that both gross savings and population growth negatively affect economic growth while energy consumption has positive impact. In the view point of Ndoricimpa (2020), Low debt is found to be growth neutral but higher public debt is growth detrimental. 
2.2 The role of credit and interest rate in the agricultural development

Theoretically, when considering the pattern of Hicks (1937) and Hansen (1953), a decrease in the interest rate has two contradictory effects: it lowers savings but increases investment; therefore, expenditure increases. Thanks to the play of the multiplier, income increases and savings in return, can adjust to a higher level (with a constant propensity to consume). An increase in the interest rate on the contrary slows investment and stimulates savings (side effect). As expenditure decreases, income falls and with it savings. Thus, there is a return to equilibrium.

Empirically, several studies have analyzed the role of credit in the development of agriculture. Rao (1970) considers credit as a means of overcoming the constraint of underutilization of capital, while Obilor (2013) analyses the impact of credit distributed by commercial banks and state allocations on agricultural productivity in the case of Nigeria. It concludes that credit has a positive effect on agricultural productivity. Das et al. (2009) assess the impact of credit on agricultural production in India in a context characterized by both a surge in the amount of credit granted to agriculture and a fall in the share of agricultural gross domestic product (GDP) in overall GDP. Using a dynamic panel of the Arellano and Bond type with the use of instrumental variables, the authors conclude that direct credit to agriculture has a positive and immediate effect on agricultural production. The main limit we find in this work is that the econometric approach used does not allow us to highlight the regional disparities that characterize India. For Anthony (2010), he examines the impact of agricultural credit on economic growth in Nigeria. He argues that agricultural credit is an effective instrument that can boost agricultural output in Nigeria. Kra (2001) shows that paddy rice farmers with access to credit and those without access to credit do not have the same economic efficiency. This difference in economic efficiency is due to a difference in technical efficiency, as all farmers have the same efficiency in resource allocation. Consequently, the study reveals that credit is an important stimulus contributing to the development of the agricultural sector. After reviewing the history of financial institutions and presenting those that currently exist, a change of approach in the management of these structures and the creation of a new agricultural bank is recommended.

However, there is some literature that suggests that credit may not be beneficial to farmers. This is the case in the work of Carter (1988), which goes beyond the fact that contractual restrictions are a source of credit rationing. Carter (1988) will argue that even unrestricted laissez-faire markets can also ration credit. A formal model, which grants borrowers autonomy in the application and use of credit, demonstrates that negative incentive and selection effects can lead banks to endogenously impose interest rate restrictions and ration small firms in the credit market. As a result, the liberalization of financial markets may not be sufficient to guarantee access to credit for small farms. Hoi and Hoi (2016), employing generalized method of moment to analyze the impact of credit market depth on income inequality in Vietnam, show that expanding credit market in this country could lead to higher income inequality. Nelson (1971) argues that technological barriers may prevent farmers from being efficient even when they have received credit. The role of the information system in the efficiency of credit to farmers is demonstrated by Steitieh (1971). Salami and Arawomo (2013) went further by arguing that a higher saving rate produces more agricultural credit.

\section{Money and credit management in the WAEMU}

The monetary policy of the Central Bank of West African States (CBWAS) is based on market mechanisms and indirect instruments for regulating liquidity, notably interest rates and the reserve requirement system $(\mathrm{BCEAO}, 2016)$. The interest rate policy, implemented within the framework of the issuing institute's refinancing windows, aims at steering short-term rates
Comparative effect of shortterm credit 
JED

24,2

180

on the money market. This steering of rates, which is carried out through open market operations and refinancing at the marginal lending window, enables the issuing institute to achieve the objective of price stability. The minimum reserve system enables the CBWAS to reduce or develop the credit distribution capacity of the banking system. Thus, all banks and credit distributing financial institutions authorized to receive deposits from the public and credit sales financing institutions are subject to minimum reserve requirements with the Central Bank.

\section{Methodology}

\subsection{The data}

The data used in this paper are based on a sample of seven (7) WAEMU countries, namely Benin, Burkina Faso, Côte d'Ivoire, Mali, Niger, Senegal and Togo. Bissau Guinea is omitted because presence of missing data. Table 1 presents the descriptive statistic of the variables.

The evolution of the agricultural financing ratio of short-term credit by country is presented in Figure 1.

From the Figure, the ratio of credit to agricultural value added is generally higher in Mali, Senegal, Burkina Faso and Côte d'Ivoire. The period 2005 to 2008 was characterized by an increase in the ratio credit-agricultural value added. This situation could be explained by the concern of States to remedy the adverse effects of food, financial and economic crisis during this period. On the other hand, this ratio is lower in Togo and Niger.

Moreover, in 2010, the ratio credit-agricultural value added was almost nil in all countries.

Figure 2 presents the real interest rate by country over the period 1995-2017.

The analysis of average real interest rates in WAEMU countries reveals the high level of cost of market financing for agriculture over the period 1995-2017 in countries such as Niger and Burkina Faso. Indeed, the average real interest rate in these countries is above $8 \%$. This rate is on average below $8 \%$ and above $7 \%$ in Benin, Côte d'Ivoire, Senegal and Togo. It is lower in Mali and is around 6\%. The increase in the cost of credit is generally attributable to loans to the public sector, private enterprises in the productive sector and financial clients.

\subsection{The models}

4.2.1 The panel autoregressive vector model (PVAR). In order to estimate IRFs and study shocks, a panel VAR model inspired by the work of Mishkin and Shmidt-Hebbel (2007) is used. The econometric model specified is as follows:

$$
y_{i t}=\tau(l) y_{i t}+u_{i}+\varepsilon_{i t}
$$

Where $y_{i t}$ is a vector of four dependent variables (ADGRIVA, AGRIPOP, CREDGANTED, REALIR); ADGRIVA the agricultural value added at constant prices in billions of FCFA [1]; AGRIPOP the agricultural population (inhabitant number); CREDGANTED the amount of short-term credit granted to the agriculture, forestry and fisheries branch declared to the Central Risk Office in millions of FCFA; REALIR the real interest rate in percentage. $\tau(l)$ is a lag operator in the form of a polynomial matrix. $u_{i}$ is a vector of a country's specific effects that is introduced in order to capture of countries heterogeneity. $\varepsilon_{i t}$ is a vector of idiosyncratic, homoscedastic and non-autocorrelated errors. Shocks are analyzed after Eqn 1 estimation.

4.2.2 The autoregressive distributed lag ( $A R D L)$ model. To make a comparative analysis of the effect of agricultural credit on agricultural value added in the WAEMU, the paper uses an autoregressive distributed lag (ARDL) model with the associated error correction model. The agricultural value added equation is an augmented Cobb-Douglas production function with the following ARDL specification: 


\begin{tabular}{|c|c|c|c|c|c|c|c|c|}
\hline & Variables & & Source & Mean & Std.-dev & Minimum & Maximum & Comparative \\
\hline \multirow[t]{4}{*}{ Bénin } & ADGRIVA & $\begin{array}{l}\text { Agricultural } \\
\text { value added } \\
\text { at constant } \\
\text { prices in } \\
\text { billions of } \\
\text { FCFA }\end{array}$ & WDI & 630 & 145 & 382 & 845 & term credit \\
\hline & CREDGANTED & $\begin{array}{l}\text { Short term } \\
\text { credit } \\
\text { granted to } \\
\text { the } \\
\text { agriculture } \\
\text { Forestry and } \\
\text { fishing } \\
\text { branch } \\
\text { declared to } \\
\text { the central } \\
\text { risk office in } \\
\text { millions of } \\
\text { FCFA }\end{array}$ & CBWAS & 8,531 & 8,104 & 0 & 33,059 & \\
\hline & AGRIPOP & $\begin{array}{l}\text { Agricultural } \\
\text { population } \\
\text { (inhabitant } \\
\text { number) }\end{array}$ & WDI & $4,857,793$ & 718,649 & $3,734,793$ & $6,045,541$ & \\
\hline & REALIR & $\begin{array}{l}\text { Real interest } \\
\text { rate }(\%)\end{array}$ & CBWAS & 12 & 5 & 0 & 19 & \\
\hline \multirow[t]{5}{*}{$\begin{array}{l}\text { Burkina } \\
\text { faso }\end{array}$} & ADGRIVA & $\begin{array}{l}\text { Agricultural } \\
\text { value added } \\
\text { at constant } \\
\text { prices in } \\
\text { billions of } \\
\text { FCFA }\end{array}$ & WDI & 765 & 179 & 444 & 987 & \\
\hline & CREDGANTED & $\begin{array}{l}\text { Short-term } \\
\text { credit } \\
\text { granted to } \\
\text { the } \\
\text { agriculture } \\
\text { Forestry and } \\
\text { fishing } \\
\text { branch } \\
\text { declared to } \\
\text { the central } \\
\text { risk office in } \\
\text { millions of } \\
\text { FCFA }\end{array}$ & CBWAS & 21,609 & 40,056 & 0 & 189,293 & \\
\hline & AGRIPOP & $\begin{array}{l}\text { Agricultural } \\
\text { population } \\
\text { (inhabitant } \\
\text { number) }\end{array}$ & WDI & $10,700,000$ & 1,345740 & $8,563,179$ & $12,900,000$ & \\
\hline & REALIR & $\begin{array}{l}\text { Real interest } \\
\text { rate }(\%)\end{array}$ & CBWAS & 12 & 5 & 0 & 19 & $\begin{array}{l}\text { Table 1. } \\
\text { Descriptive statistic of } \\
\text { the variables of the }\end{array}$ \\
\hline & & & & & & & (continued) & \\
\hline
\end{tabular}




\begin{tabular}{|c|c|c|c|c|c|c|c|}
\hline & Variables & & Source & Mean & Std.-dev & Minimum & Maximum \\
\hline \multirow[t]{4}{*}{$\begin{array}{l}\text { Côte } \\
\text { d'Ivoire }\end{array}$} & ADGRIVA & $\begin{array}{l}\text { Agricultural } \\
\text { value added } \\
\text { at constant } \\
\text { prices in } \\
\text { billions of } \\
\text { FCFA }\end{array}$ & WDI & 2,110 & 495 & 1,470 & 3,030 \\
\hline & CREDGANTED & $\begin{array}{l}\text { Short-term } \\
\text { credit } \\
\text { granted to } \\
\text { the } \\
\text { agriculture } \\
\text { Forestry and } \\
\text { fishing } \\
\text { branch } \\
\text { declared to } \\
\text { the central } \\
\text { risk office in } \\
\text { millions of } \\
\text { FCFA }\end{array}$ & CBWAS & 36,555 & 31,040 & 0 & 134,569 \\
\hline & AGRIPOP & $\begin{array}{l}\text { Agricultural } \\
\text { population } \\
\text { (inhabitant } \\
\text { number) }\end{array}$ & WDI & $9,755,769$ & 577,706 & $8,548,548$ & $10,700,000$ \\
\hline & REALIR & $\begin{array}{l}\text { Real interest } \\
\text { rate }(\%)\end{array}$ & CBWAS & 12 & 5 & 0 & 17 \\
\hline \multirow[t]{4}{*}{ Mali } & ADGRIVA & $\begin{array}{l}\text { Agricultural } \\
\text { value added } \\
\text { at constant } \\
\text { prices in } \\
\text { billions of } \\
\text { FCFA }\end{array}$ & WDI & 961 & 285 & 615 & 1,550 \\
\hline & CREDGANTED & $\begin{array}{l}\text { Short-term } \\
\text { credit } \\
\text { granted to } \\
\text { the } \\
\text { agriculture } \\
\text { Forestry and } \\
\text { fishing } \\
\text { branch } \\
\text { declared to } \\
\text { the central } \\
\text { risk office in } \\
\text { millions of } \\
\text { FCFA }\end{array}$ & CBWAS & 49,976 & 49,592 & 0 & 247,595 \\
\hline & AGRIPOP & $\begin{array}{l}\text { Agricultural } \\
\text { population } \\
\text { (inhabitant } \\
\text { number) }\end{array}$ & WDI & $8,844,947$ & $1,115,545$ & $7,153,490$ & $10,700,000$ \\
\hline & REALIR & $\begin{array}{l}\text { Real interest } \\
\text { rate }(\%)\end{array}$ & CBWAS & 9 & 4 & 0 & 14 \\
\hline
\end{tabular}

Table 1. 


\begin{tabular}{|c|c|c|c|c|c|c|c|c|}
\hline & Variables & & Source & Mean & Std.-dev & Minimum & Maximum & Comparative \\
\hline \multirow[t]{4}{*}{ Niger } & ADGRIVA & $\begin{array}{l}\text { Agricultural } \\
\text { value added } \\
\text { at constant } \\
\text { prices in } \\
\text { billions of } \\
\text { FCFA }\end{array}$ & WDI & 711 & 399 & 298 & 1,410 & term credit \\
\hline & CREDGANTED & $\begin{array}{l}\text { Short-term } \\
\text { credit } \\
\text { granted to } \\
\text { the } \\
\text { agriculture } \\
\text { Forestry and } \\
\text { fishing } \\
\text { branch } \\
\text { declared to } \\
\text { the central } \\
\text { risk office in } \\
\text { millions of } \\
\text { FCFA }\end{array}$ & CBWAS & 1,589 & 1,154 & 0 & 5,010 & \\
\hline & AGRIPOP & $\begin{array}{l}\text { Agricultural } \\
\text { population } \\
\text { (inhabitant } \\
\text { number) }\end{array}$ & WDI & $11,800,000$ & $2,705,051$ & $7,982,473$ & $16,700,000$ & \\
\hline & REALIR & $\begin{array}{l}\text { Real interest } \\
\text { rate }(\%)\end{array}$ & CBWAS & 13 & 5 & 0 & 17 & \\
\hline \multirow[t]{5}{*}{ Sénégal } & ADGRIVA & $\begin{array}{l}\text { Agricultural } \\
\text { value added } \\
\text { at constant } \\
\text { prices in } \\
\text { billions of } \\
\text { FCFA }\end{array}$ & WDI & 576 & 107 & 426 & 822 & \\
\hline & CREDGANTED & $\begin{array}{l}\text { Short-term } \\
\text { credit } \\
\text { granted to } \\
\text { the } \\
\text { agriculture } \\
\text { Forestry and } \\
\text { fishing } \\
\text { branch } \\
\text { declared to } \\
\text { the central } \\
\text { risk office in } \\
\text { millions of } \\
\text { FCFA }\end{array}$ & CBWAS & 22,430 & 10,655 & 0 & 44,662 & \\
\hline & AGRIPOP & $\begin{array}{l}\text { Agricultural } \\
\text { population } \\
\text { (inhabitant } \\
\text { number) }\end{array}$ & WDI & $6,796,893$ & $1,037,160$ & $5,281,201$ & $8,620,486$ & \\
\hline & REALIR & $\begin{array}{l}\text { Real interest } \\
\text { rate }(\%)\end{array}$ & CBWAS & 11 & 4 & 0 & 14 & \\
\hline & & & & & & & (continued) & Table 1. \\
\hline
\end{tabular}




\begin{tabular}{|c|c|c|c|c|c|c|c|}
\hline & Variables & & Source & Mean & Std.-dev & Minimum & Maximum \\
\hline \multirow[t]{4}{*}{ Togo } & ADGRIVA & $\begin{array}{l}\text { Agricultural } \\
\text { value added } \\
\text { at constant } \\
\text { prices in } \\
\text { billions of } \\
\text { FCFA }\end{array}$ & WDI & 357 & 449 & 273 & 459 \\
\hline & CREDGANTED & $\begin{array}{l}\text { Short-term } \\
\text { credit } \\
\text { granted to } \\
\text { the } \\
\text { agriculture } \\
\text { Forestry and } \\
\text { fishing } \\
\text { branch } \\
\text { declared to } \\
\text { the central } \\
\text { risk office in } \\
\text { millions of } \\
\text { FCFA }\end{array}$ & CBWAS & 814 & 715 & 0 & 2,488 \\
\hline & AGRIPOP & $\begin{array}{l}\text { Agricultural } \\
\text { population } \\
\text { (inhabitant } \\
\text { number) }\end{array}$ & WDI & $3,733,986$ & 482,980 & $2,961,685$ & $4,528,607$ \\
\hline & REALIR & Real interest & CBWAS & 11 & 5 & 0 & 15 \\
\hline
\end{tabular}

Table 1.

Note(s): WDI: World Development Indicators; CBWAS: Central Bank of West African States

$$
\text { LADGRIVA }_{t}=\alpha_{0}+\alpha_{1} \text { LAGRIPOP }_{t}+\alpha_{2} \text { LCREDGANTED }_{t}+\alpha_{3} \text { REALIR }_{t}+\varepsilon_{t}
$$

The error correction model associated to Eqn (2) is represented as:

$$
\begin{aligned}
\Delta \text { LADGRIVA }_{t}= & \beta_{0}+\sum_{j=1}^{n} \beta_{j} \Delta \text { LAGRIPOP }_{t-j}+\sum_{j=1}^{n} \delta_{j} \text { LCREDGANTED }_{t-j} \\
& +\sum_{j=1}^{n} \sigma_{j} \operatorname{REALIR}_{t-j}+E C M_{t-1}+\varepsilon_{t}
\end{aligned}
$$

Table 2 presents the different variables and their descriptions.

To estimate Eqn (2), the paper uses the ARDL approach. There are two main cointegration approaches before ARDL (Pesaran and Shin, 1995) after the first original attempts by Engle and Granger (1987): the first is the approach of Johansen (1988) and Johansen and Juselius (1994) and the second is the FMOLS of Philip and Hansen (1990). According to Oloukoi (2016, 2020), ARDL approach presents several advantages: it is an approach that does not proceed in stages, unlike the approach of Engel and Granger (1987); it is an approach that does not require a large number of observations unlike other approaches; it is therefore an appropriate model for our countries where there is a severe lack of data; it is an approach that does not require the variables to be necessarily integrated in the same order, the variables can be $\mathrm{I}(0)$ and/or I(1) contrary to Johansen's (1988) technique; it is based on Schwarz's information criterion (SBC) to determine the optimal lags and the optimal models, and SBC is now seen as 
Comparative effect of shortterm credit

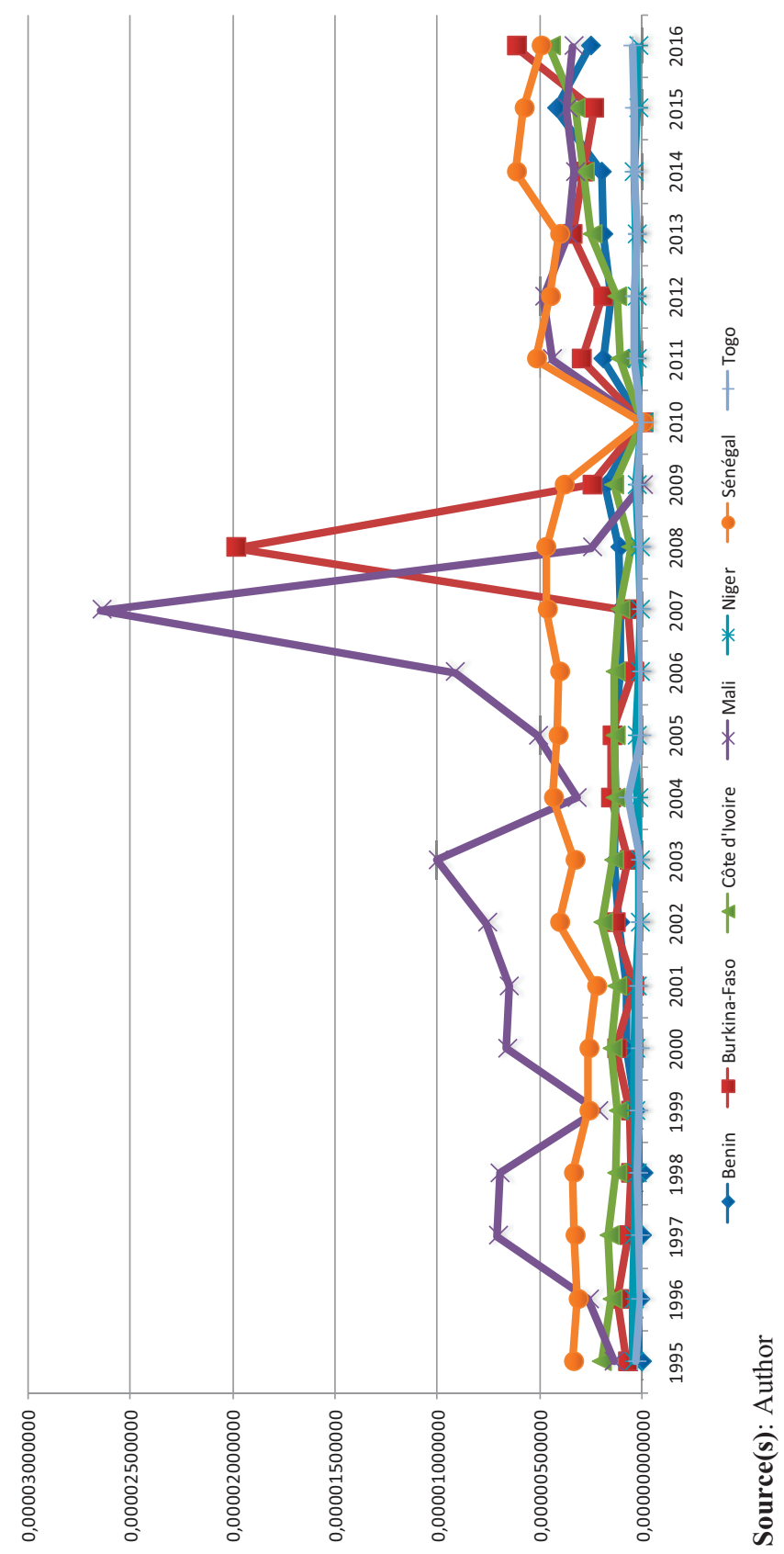

Figure 1. Evolution of ratio short-term creditagricultural value added by country from 1995 to 2016 


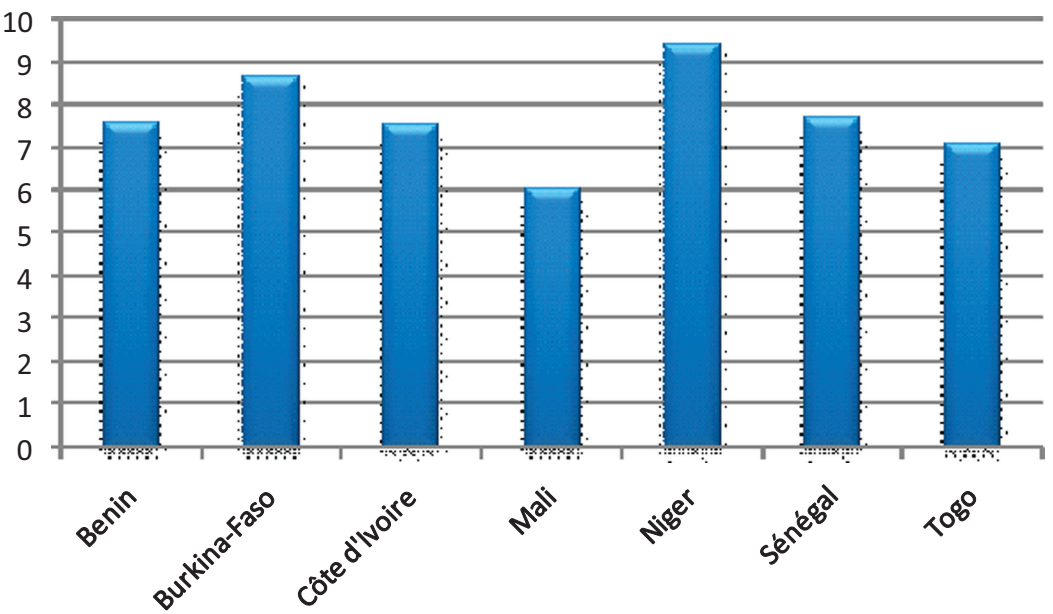

Real interest rate by country (average 1995-2016)

Source(s): Author

\begin{tabular}{lll}
\hline $\begin{array}{l}\text { Variables/ } \\
\text { Parameters }\end{array}$ & Description & $\begin{array}{l}\text { Expected } \\
\text { signs }\end{array}$ \\
\hline LADGRIVA & $\begin{array}{l}\text { Neperian logarithm of agricultural value added at constant prices in } \\
\text { billions of FCFA }\end{array}$ & $+/-$ \\
LAGRIPOP & $\begin{array}{l}\text { Neperian logarithm of agricultural population } \\
\text { Neperian logarithm of short-term credit granted to the agriculture, } \\
\text { fCREDGANTED }\end{array}$ & + \\
REALIR & $\begin{array}{l}\text { Real interest rate } \\
\text { Constant }\end{array}$ & + \\
$\alpha_{0}$ & Parameters & \\
$\alpha_{1,} \alpha_{2,} \alpha_{3}$ & &
\end{tabular}

the best criterion; it is an approach that represents a credible alternative in the modeling of serial auto-correlation of errors and endogeneity of repressors, unlike Fully Modified Ordinary Least (FMOLS) in particular.

\section{Results and discussions}

The analysis of the results and discussions are presented in this section. It is devoted to the analysis of effect of credit on agricultural added value (subsection 1) and of IRFs following credit and interest rate shocks (subsection 2). The analysis of the comparative effect of agricultural credit and interest rates on agricultural value added in WAEMU countries is done in subsection 3 .

\subsection{Effect of short-term credit granted to agriculture on agricultural added value in the West African Countries}

The results of the effect of short-term credit granted to agriculture on agricultural added value in the West African Countries are presented in Table 3. We use the Panel vector autoregression with GMM estimation to estimate equation 1. 
According to Table 3, credit has a positive effect on agricultural added value in the West African Countries. This result confirm the conclusions of Rao (1970), Obilor (2013), Das et al. (2009), Kra (2001) and Anthony (2010) on the positive role of credit in the agricultural development.

\subsection{Shocks and impulse response functions}

In this subsection, we analyze the responses of agricultural value added to credit and real interest rate shocks. Those responses result from Eqn 1 estimation present on Table 3.

5.2.1 Response of agricultural value added to agricultural credit shocks. Figure 3 presents the transmission of credit shocks to agricultural value added in the WAEMU.

As a result of a credit shock to agriculture, agricultural value added began to fall sharply and significantly until it reached its lowest level after about a year and a half. A positive agricultural credit shock initially reduces agricultural value added. However, this depression corrects itself very quickly, practically from three years onwards. This effect does not fade away.

In other words, the analysis of Figure 3 indicates that agricultural value added falls sharply by about six-quarters. This fall becomes slow from the sixth quarter to the twelfth quarter. From the second year onward, there is a kind of permanent recovery.

These results suggest that credit is beneficial to the improvement in value added. This positive effect is only noticeable in the medium and long term. Credit only becomes a means of lifting the constraint of capital underutilization from three years onward in the WAEMU countries. Credit, by enabling farmers to improve their productivity in the logic of Obilor (2013), thus remains a key factor for agricultural growth in the zone.

Our result does not however go in the direction of that found by Das et al. (2009) in India in a context characterized by both a surge in the amount of credit granted to agriculture and a

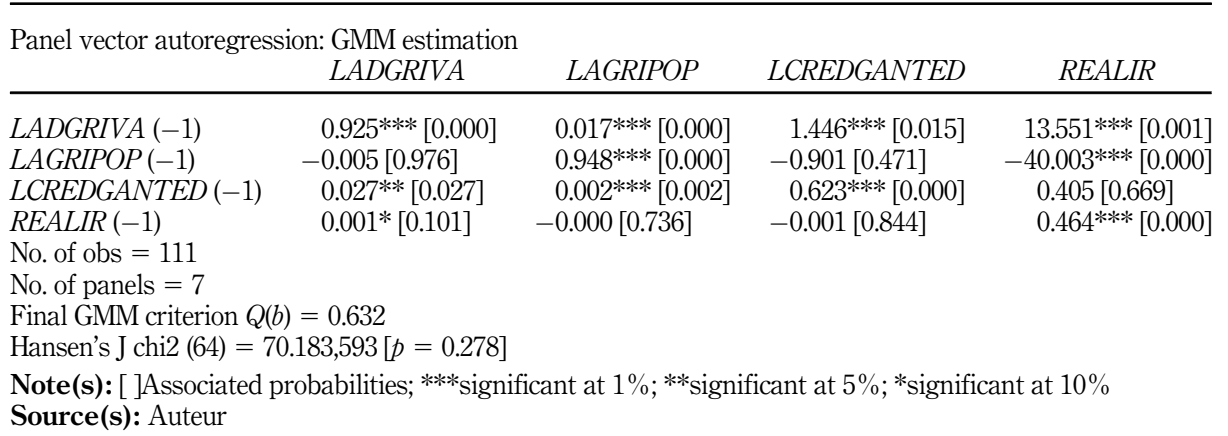

$$
\text { a context characterized by both a surge in the amount of credit granted to agriculture and a }
$$

Comparative effect of shortterm credit

187


JED

24,2

188

fall in the share of agricultural GDP in overall GDP. For Das et al. (2009), direct credit to agriculture has a positive and immediate effect on agricultural production. For us, the effect is not immediate but only occurs after two and a half or three years in the WAEMU.

5.2.2 Response of agricultural value added to interest rate shocks. Figure 4 shows the impulse responses to a real interest rate shock.

An interest rate shock has a sudden and significant depressing effect on agricultural value added in the first phase and during the first four trimesters. In a second phase, the effect becomes positive from one year onward, reaching its peak around four years. Unfortunately, this positive effect will start to decline from the fifth year onward.

In view of this result, we can state that a real interest rate shock does not have a univocal effect on agricultural value added in the WAEMU. According to Figure 4, in the short and long term, a positive interest rate shock has a depressing effect on agricultural value added in this sub-region. On the other hand, in the midterm (between 2 and 4 years), the effect is beneficial because it stimulates value added.

The high cost of credit to agriculture remains a brake on the growth of agricultural value added in the WAEMU in the short and long term. In order to increase agricultural value added, a policy of lowering real interest rates must be prioritized, but this must be done in the midterm. Since the fall in interest rates only has a positive impact on agricultural value added in the midterm, other measures will have to be taken to accompany the fall in interest rates in order to maintain the trend in value added in the long term. Among these measures are the improvement of the quality of the labor force and the increase in the amount of credit allocated to the agricultural sector.

\subsection{Comparative effect of credit to agriculture and the real interest rate on agricultural value added in the WAEMU}

The results of the ARDL model estimation are presented in Table 4 for each WAEMU country.

Looking at Table 4, short-term credit granted to agriculture in the WAEMU has a weak and differentiated effect on agricultural value added from one country to another. This effect is negative for some countries (Burkina Faso, Niger and Senegal) and positive for others (Benin, Côte d'Ivoire, Mali and Togo). While for Côte d'Ivoire the effect is positive and significant, we note for the other countries that credit does not have a significant impact on value added. Agricultural credit is therefore not yet an effective instrument that can stimulate agricultural output in the most WAEMU countries.

With regard to the real interest rate, estimates show that a positive shock on the real interest rate has a negative effect on agricultural value added in most WAEMU countries. This effect is small in general, but it is significant only in Burkina Faso and Côte d'Ivoire. An

Figure 4.

Transmission of real interest rate shocks to agricultural value added in the WAEMU

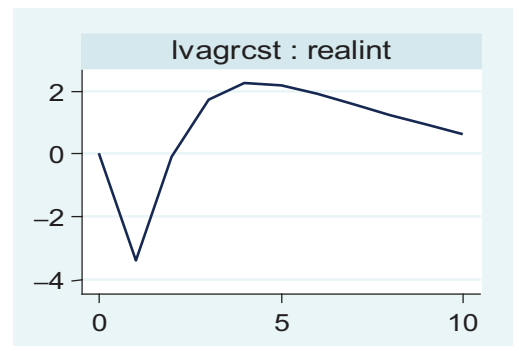

Source(s): Author 


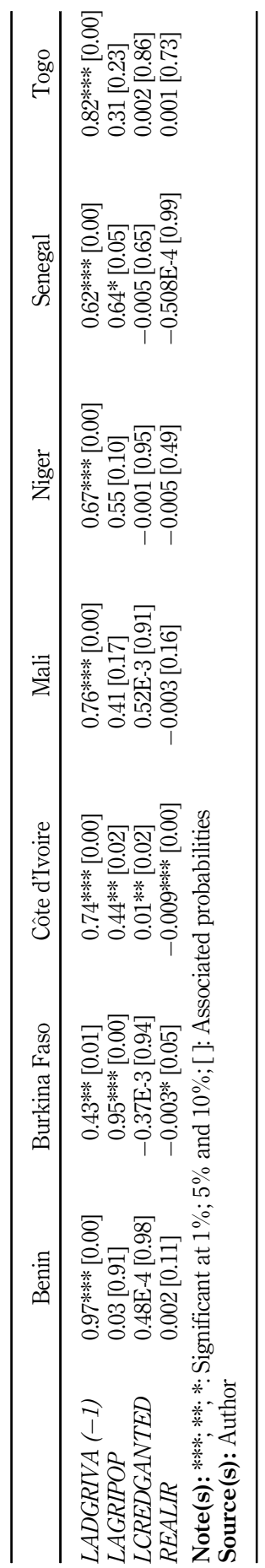

Comparative effect of shortterm credit

189

Table 4. ARDL model estimation for agricultural value added in WAEMU 
JED

24,2

increase in the real interest rate, by curbing investment, leads to a decline in spending on agricultural projects as a result of increased savings. A decrease in the interest rate is beneficial for agriculture in these countries due to lower savings and increased investment. In this condition, credit becomes an instrument to overcome the constraint of underutilization of capital (Rao, 1970). If interest rates fall, it is naturally not in the interest of the banks to adjust their lending cost as quickly as possible, at least if competition allows them to do so. They do not necessarily have an incentive to pass on rate increases in full. In fact, raising the interest rates may trigger a selection phenomenon.

\section{Conclusion and recommendations}

The purpose of this study is twofold: to analyze the responses of agricultural value added in the WAEMU to credit and real interest rate shocks on one hand, and on the other, to make a comparative effect analysis of short-term credit granted to the agricultural sector on agricultural value added among member countries. We used a panel vector autoregressive (PVAR) model to analyze the responses of agricultural value added and an ARDL model for the comparative analysis of the effect of short-term credit.

The stylized facts show that the ratio of short-term credit to agricultural value added is generally higher in Mali, Senegal, Burkina Faso and Côte d'Ivoire, while it is lower in Togo and Niger. Over the period 2005 to 2008, we observe an upward trend in the ratio of credit to agricultural value added. This situation could be explained by the States' concern to remedy the adverse effects of the food, financial and economic crisis of this period. Analysis of average real interest rates in WAEMU countries reveals the increase in the cost of market financing for agriculture over the period 1995-2017 in countries such as Niger and Burkina Faso.

With regard to the responses of agricultural value added to credit and real interest rate shocks, it emerges, on one hand that a positive shock on credit to agriculture lowers agricultural value added initially and, on the other hand that an interest rate shock has a sudden and significant depressing effect on agricultural value added in the first four trimesters. As regards the comparative analysis effect of short-term credit on the agricultural sector between countries, short-term credit granted to agriculture in the WAEMU has a weak and differentiated effect on agricultural value added from one country to another. This effect is negative for some countries (Burkina Faso, Niger, Senegal) and positive for others (Benin, Côte d'Ivoire, Mali, Togo).

In view of our results, it is imperative to implement a policy of lowering real short-term interest rates. Lowering the real interest rate, by lowering the cost of credit, contributes to lowering production costs. Lower costs will have two effects. On one hand, through the substitution effect (price effect), agriculture will be able to reap gains in competitiveness on external markets, especially in sectors exposed to international competition: anything that improves the agricultural trade balance of countries. On the other hand, lower costs, by improving margins, will contribute to improving profitability: anything that helps to ease financial constraints, particularly in terms of investment in agriculture. Moreover, a monetary policy that favors direct financing of agriculture to the detriment of that oriented toward market financing is to be prioritized. Therefore, the paper strongly recommends the implementation of framework policies and credit selectivity in favor of agriculture. All these measures must be coupled with the definition of a target amount of credit to be granted to agriculture per country.

\section{Note}

1. Franc de la Communauté Financière Africaine 


\section{References}

Anetor, F.O. (2018), "Economic growth effect of private capital inflows: a structural VAR approach for Nigeria”, Journal of Economics and Development, Vol. 21 No. 1, pp. 18-29, doi 10.1108/JED-062019-0009.

Anthony, E. (2010), "Agricultural credit and economic growth in Nigeria: an empirical analysis", Business and Economics Journal, Vol. 2010 BEJ-14, pp. 1-7.

Anyanwu, J.C. (2011), "Aid and economic growth in Africa: empirical evidence from recent data, 1958 2001", in Gbetnkom, D. (Ed.), International Finance: Theory and Policy in Africa, Author House, Bloomington, IN, pp. 167-89.

Anyanwu, J.C. (2014), "Factors affecting economic growth in Africa: are there any lessons from China?", African Development Review, Vol. 26 No. 3, pp. 468-493.

Barro, R.J. (2003), "Determinants of economic growth in a panel of countries", Annals of Economics and Finance, Vol. 4, pp. 231-74.

BCEAO (2016), "Collection of legal and regulatory texts governing banking and financial activity in the West African Monetary Union. Chapter II: Implementation of the monetary policy and credit”, Central Bank of West African States, Dakar (in French).

Blecker, R.A. (2010), "Long-run growth in open economies: export-led cumulative causation or a balance-of-payments constraint?", in Harcourt, G. and Kriesler, P. (Eds), Handbook of PostKeynesian Economics, Vol. 1, Oxford University Press, 2013, forthcoming.

Carter, M.R. (1988), "Equilibrium credit rationing of small farm agriculture", Journal of Development Economics, Vol. 28 No. 1, pp. 83-103.

Chenery, H.B. and Strout, A.M. (1968), "Foreign assistance and economic development: reply", The American Economic Review, Vol. 58 No. 4, pp. 912-916.

Das, A., Senapati, M. and John, J. (2009), "Impact of agricultural credit on agriculture production: an empirical analysis in India”, Reserve Bank of India Occasional Papers, Vol. 30 No. 2, pp. 75-107.

Duncan, R. and Quang, D. (2001), "The role of institutions in the development of Vietnam", ASEAN Economic Bulletin, Vol. 18 No. 3, pp. 276-288.

Engle, R.F. and Granger, C.W.J. (1987), "Co-integration and error-correction: representation, estimation and testing”, Econometrica, Vol. 55, pp. 987-1008.

Ferro, E., Portugal-Pérez, A. and Wilson, J.S. (2011), "Aid to the services sector: does it affect manufacturing exports?”, Policy Research Working Paper n5728, The World Bank, pp. 1-30.

Gatsi, J.G. and Appiah, M.O. (2020), "Population growth, income growth and savings in Ghana", Journal of Economics and Development, Vol. 22 No. 2, pp. 281-296, doi: 10.1108/JED-122019-0078.

Hansen, A. (1953), A Guide to Keynes, McGraw-Hill, New York, NY.

Harrod, R.F. (1933), International Economics, Nisbet \& Cambridge University Press, Cambridge, p. 211.

Hicks, J.R. (1937), “Mr. Keynes and the 'classics'; a suggested interpretation”, Econometrica: Journal of the Econometric Society, Vol. 5 No. 2, pp. 147-159.

Hoi, L.Q. and Hoi, C.M. (2016), "Credit market depth and income inequality in Vietnam: a panel-data analysis", Journal of Economics and Development, Vol. 18 No. 2, pp. 5-18.

Hussain, N. (2002), "The balance-of-payments constrained and growth rate differences among African and East Asian Economies", African Development Review, Vol. 11 No. 1, pp. 103-137.

Johansen, S. (1988), "Statistical analysis of cointegration vectors", Journal of Economic Dynamics and Control, Vol. 12 No. 2-3, pp. 231-254.

Johansen, S. and Juselius, K. (1994), "Identification of the long-run and the short-run structure an application to the ISLM model”, Journal of Econometrics, Vol. 63 No. 1, pp. 7-36.

Comparative effect of shortterm credit

\section{.}


Johnston, B.F. and Mellor, J.W. (1961), "The role of agriculture in economic development", The American Economic Review, Vol. 51 No. 4, pp. 566-593.

Khan, M.H. (1967), “The role of agriculture in economic development: a case study of Pakistan'. Review by: Willis D. Weatherford”, The American Economic Review, Vol. 57 No. 5, pp. 1410-1411.

Kra, D.K. (2001), "Agricultural credit and efficiency of agricultural production in Côte d'Ivoire", Rural Economy, No. 263, pp. 92-104 (in French).

Kuznets, S. (1971), 8. Notes on Stage of Economic Growth as a System Determinant, University of California Press, pp. 243-268.

Lensink, R. and Morrissey, O. (1999), "Aid instability as a measure of uncertainty and the positive impact of aid on growth", available at: http://irs.ub.rug.nl/ppn/241140455.

Mayer, F. and Milberg, W. (2013), "Aid for trade in a world of global value chains: chain power, the distribution of rents and implications for the form of aid", Working Paper 34, Capturing the Gains, The University of Manchester.

Mishkin, F.S. and Schmidt-Hebbel, K. (2007), “Does inflation targeting make a difference?”, NBER Working Paper series 12876, NBER, pp. 1-66, available at: http://www.nber.org/papers/w12876.

Ndoricimpa, A. (2020), "Threshold effects of public debt on economic growth in Africa: a new evidence", Journal of Economics and Development, Vol. 22 No. 2, pp. 187-207.

Nelson, W.C. (1971), An Economic Analysis of Fertilizer Utilization in Brazil, The Ohio State University, University Microfilms, A XEROX Company, Ann Arbor, Michigan.

Obilor, S.I. (2013), “The impact of commercial banks' credit to agriculture on agricultural development in Nigeria: an econometric analysis", International Journal of Business, Humanities and Technology, Vol. 3 No. 1, pp. 85-94.

Oloukoi, L. (2016), Politiques agricoles et compétitivité de l'agriculture au Bénin, Editions Universitaires Européennes, Saarbrücken.

Oloukoi, L. (2020), "Demande extérieure et offre agricole de long terme: cas des noix de cajou dans l'Union Economique et Monétaire Ouest-Africaine (UEMOA)", African Development Review, Vol. 2020, pp. 1-13, doi: 10.1111/1467-8268.12454.

Ozturk, I. and Acaravci, A. (2010), "An application of Thirlwall's law to the South African economy : evidence from ARDL bounds testing approach", African Journal of Business Management, Vol. 4 No. 2, pp. 262-266.

Pesaran, M.H. and et Smith, R. (1995), "The role of theory in econometrics", Journal of Econometrics, Vol. 67, pp. 61-79.

Phillips, P.C.B. and Hansen, B.E. (1990), "Statistical inference in instrumental variables regression with I(1) process", Review of Economic Studies, Vol. 57, pp. 99-125.

Rao, B.P. (1970), "The economics of agricultural credit-use in southern Brazil", PhD thesis, Ohio State University, University Microfilms, A XEROX Company, Ann Arbor, Michigan.

Rosenstein-Rodan, P.N. (1961), "International aid for underdeveloped countries", The Review of Economics and Statistics, Vol. XLIII No. 2, pp. 107-138.

Ruan, J. (2017), "Development economics: the role of agriculture in development", China Agricultural Economic Review, Vol. 9 No. 1, pp. 156-158, doi: 10.1108/CAER-08-2016-0134.

Salami, A. and Arawomo, D.F. (2013), "Empirical analysis of agricultural credit in Africa: any role for institutional factors?”, Working Paper Series No 192, African Development Bank, Tunis, Tunisia.

Setterfield, M. (2003), "Supply and demand in theory of long run growth: introduction to a symposium on demand-led growth", Review of Political Economy, Taylor and Francis Journals, Vol. 15 No. 1, pp. 23-32.

Steitieh, A.M. (1971), Input Productivity and Productivity Change of the Crop Enterprise in Southern Brazil, The Ohio State University, University Microfilms, A XEROX Company, Ann Arbor, Michigan. 
Thirlwall, A.T. (1979), "The balance of payments constrained as an explanation of international growth rate differences”, Banca Nazionale del lavoro Quarterly Review, Vol. 128, pp. 44-53.

Vickers, J. and Yarrow, G. (1991), "Economic perspectives on privatization”, The Journal of Economic Perspectives, Vol. 5, pp. 111-132.

Comparative effect of shortterm credit

Yongbok, J. (2009), "Balance-of-payment constrained growth: the case of China, 1979-2002", International Review of Applied Economics, Vol. 23 No. 2, pp. 135-146.

Corresponding author

Laurent Oloukoi can be contacted at: loloukoi@gmail.com 
JED

Appendix 1

24,2

Impulse responses

194
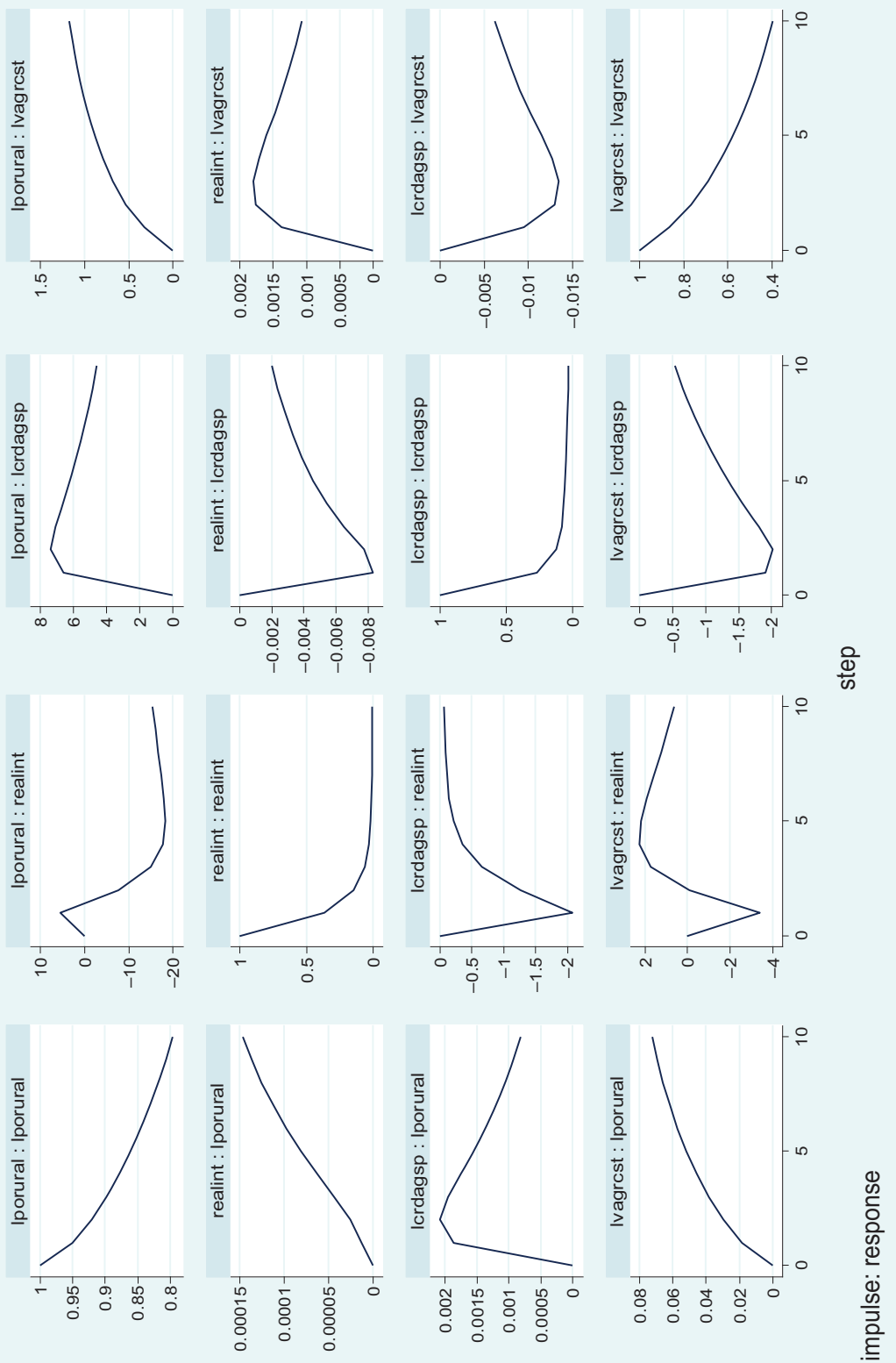

Appendix 1.

Jلالا 
Appendix 2.

Comparative effect of shortterm credit

195
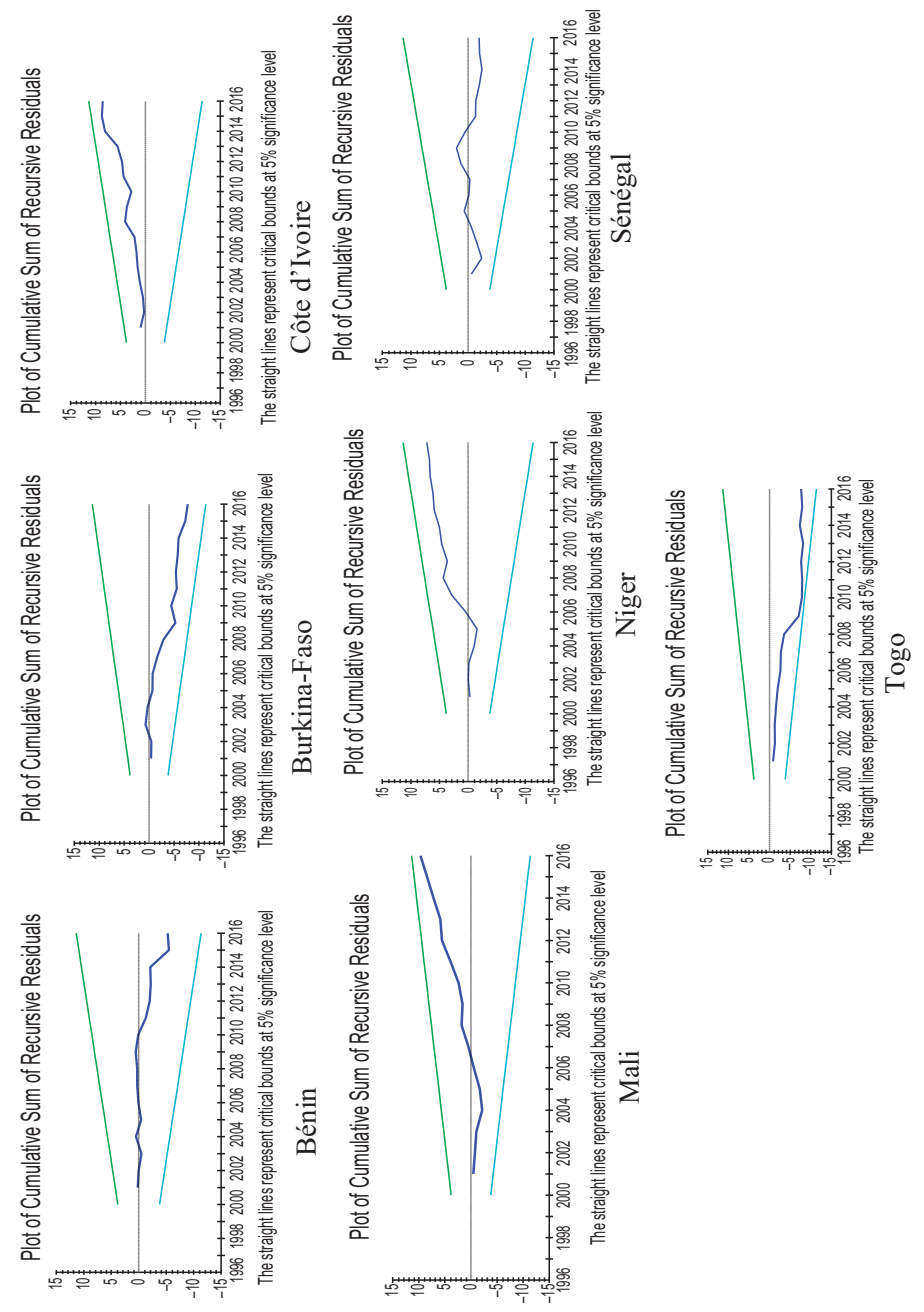

Appendix 2. 